UDC 691

Author: : Saaid I. ZAKI, Professor in Hosing and Building National Research Center HBRC , Cairo, Egypt ; Tahreer street, 87, dokki, Cairo, Egypt; 11511, Post box no 1770, saaid_zaki@yahoo;

Author: Hossam A. HODHOD, Professor in Faculty of Engineering Cairo University, Cairo, Egypt; Tahreer street, 87, dokki, Cairo, Egypt; 11511, Post box no 1770, saaid_zaki@yahoo;

Author: Mostafa A. MAHDI, Assistant Lecturer in Faculty of Engineering, Misr University for Science and Technology, Giza, Cairo, Egypt ; Tahreer street, 87, dokki, Cairo, Egypt; 11511, Post box no 1770, saaid_zaki@yahoo.

\title{
THE EFFECT OF USING HYBRID NANOMATERIALS ON DRYING SHRINKAGE AND STRENGTH OF CEMENT PASTES
}

Extended Abstract:

The aim of this work is to study the effect of nanomaterials on the properties of cement paste, the experimental program included three parts: a- two types of nanosilica, locally produced NS1 and imported NS2, b- nanoclay (NC) and c- Hybrid nanoparticles (NS1 \& NC). In each part, cement paste was used with different percentages of nanoparticles. Compressive strength and drying shrinkage tests were applied in each part on the cured and uncured samples. The results showed that the compressive strength improved in the cement paste mixtures in the cured condition, the optimum percentages was $1 \%$ for NS1, $1 \%$ for $\mathrm{NS} 2,5 \%$ for $\mathrm{NC}$, and $5 \%$ (0.5\% NS1 \& 4.5\% NC) for hybrid nanoparticles. The drying shrinkage increases with adding nanosilica and hybrid nanoparticles, while it decreases when adding NC.

Key words: nanosilica, nanoclay, hybrid nanomaterials. 
MACHINE-REAdABLE INFORMATION ON CC-LICENSES (HTML-CODE) IN METADATA OF THE PAPER

$<$ a rel=»license» href=»http://creativecommons.org/licenses/by/4.0/» $><$ img alt=»Creative Commons License» style=»borderwidth:0» src=»https://i.creativecommons.org/l/by/4.0/88x31.png» $/></ \mathrm{a}><$ br $/><$ span xmlns:dct=»http://purl.org/ $\mathrm{dc} /$ terms/» href=»http://purl.org/dc/dcmitype/Text» property=»dct:title» rel=»dct:type»>The effect of using hybrid nanomaterials on drying shrinkage and strength of cement pastes $</$ span $>$ by $<$ a xmlns:cc=»http://creativecommons.org/ ns\#» href=» Nanotehnologii v stroitel'stve = Nanotechnologies in Construction. 2016, Vol. 8, no. 2, pp. 109-134. DOI: dx.doi. org/10.15828/2075-8545-2016-8-2-109-134» property=»cc:attributionName» rel=»cc:attributionURL» $>$ Zaki Saaid I.,

Hossam A. Hodhod, Mostafa A. Mahdi. </a $>$ is licensed under a < a rel=»license» href=»http://creativecommons.org/licenses/ by/4.0/» $>$ Creative Commons Attribution 4.0 International License $</ \mathrm{a}>$. $<$ br $/>$ Based on a work at $<$ a xmlns:dct=»http:// purl.org/dc/terms/» href=» http://nanobuild.ru/en_EN/nanobuild-2-2016/» rel=»dct:source»> http://nanobuild.ru/ en_EN/nanobuild-2-2016/</a $>$. $<$ br $/>$ Permissions beyond the scope of this license may be available at $<$ a xmlns:cc=»http: // creativecommons.org/ns\#»href=»saaid_zaki@yahoo»rel=»cc:morePermissions»>saaid_zaki@yahoo</a>.

\section{Introduction}

Previous researches concerning the effect of hybrid nanomaterials on the drying shrinkage of cement pastes, mortars and concretes are so limited, as most of the following previous researches deals mainly with the dispersion issue and the influence of hybrid nanomaterials, NS and NC on the properties of fresh and hardened states.

M.A. Mahdi [1] (2015) studied the Effect of Using Nanomaterials on the Properties of Cement Paste and Mortar, He found that the compressive strength improved in the mixtures in the cured condition, the optimum percentages was $1 \%$ for nano silica, $5 \%$ for nano clay, and $5 \%$ $(0.5 \%$ NS\& $4.5 \%$ NC) for hybrid nanoparticles. The drying shrinkage and thermal conductivity increase with adding NS and Hybrid, while they decrease when adding NC.

A.M. Mohamed [2] (2014) studied the Influence of Nanomaterials on Compressive Strength of Concrete, he added nano silica, nano clay or both together with different percentages to the mixes. He found that, NS is more effective than $\mathrm{NC}$ and wet mix gives higher efficiency than dry mix. Adding NS and NC together in the mix had a remarkable improvement appearing in concrete compressive strength than using the same percentage of one type. The optimum percentages were $3 \%$ nanoparticles consisting of $25 \% \mathrm{NS}$ and $75 \% \mathrm{NC}$ for compressive strength.

I. Sobhy [3] (2012) studied the effect of using nano silica, nano clay and composite of them on the performance of concrete mixes and found 
that using nanoparticles improves the mechanical properties of concrete mixes. The optimum percentage of NS and NC was $5 \%$, and for hybrid was $2.5 \%$ NS \& $2.5 \%$ NC. Dry mix gives the best dispersion of nanoparticles and less weak points of the inert materials in the mix compared to wet mix.

M.S. Morsy, et al [4] (2010) studied the Hybrid Effect of Carbon Nanotube and Nano-Clay on Physico-Mechanical Properties of Cement Mortar, They found that adding 6\% $\mathrm{NC}$ in cement mortar increases compressive strength by $18 \%$. The addition of CNTs (up to $0.02 \%$ ) to NC cement mortar improves the compressive strength of the composites with $11 \%$ higher than mix containing $6 \% \mathrm{NC}$, while the addition of CNTs by $0.1 \%$ decreased the compressive strength.

H. Yang [5] (2012) studied the bending tensile Strength and Shrinkage Property of Nano Silica Powder Concrete; He found that when proper content of NS is added to concrete, bending tensile strength can be improved but this leads to higher shrinkage rate, easily producing early crack.

A. Sadrmomtazi, et al [6] (2010) studied the effect of Polypropylene fibers on the mechanical and physical properties of mortars containing nano- $\mathrm{SiO}_{2}$. Compressive, flexural strength and shrinkage were measured. They found that adding NS to fiber reinforced cement composites improved the mechanical characteristics of mortars, but increases shrinkage rate.

Tobón J.I., et al [7] (2010) Analyzed the Performance of Portland Cement Blended with Nano Silica and Silica Fume, measuring the physical properties cement type III replaced with $1,3,5$ and 10\% NS and silica fume in percentages of 5, 10 and $15 \%$. They found that $5 \%$ NS improves in compressive strength with $10 \%$ after 3 days of curing, while $5 \%$ and $10 \%$ NS improve in compressive strength with $10 \%$ and $80 \%$ respectively after 28 days of curing.

J.S. Belkowitz1, et al [8] (2010) investigated Nano Silica in the Cement Hydration Process determining the compressive strength. They found that different sizes of silica improve some properties. When the silica particle size increases, the rate of early pozzolanic reaction decreases. Both nano and micron size silica particles were added at the same concentration, but the nano silica was more effective.

A. Sadrmomtazi, et al [9] (2009) studied the effect of adding nano- $\mathrm{SiO}_{2}$ and silica fume (SF) to cement mortar. They found that the optimum nano- 
$\mathrm{SiO}_{2}$ percentage ranges between $5 \%$ and $7 \%$. Adding nano- $\mathrm{SiO}_{2}$ increased drying shrinkage and decreased the water absorption of cement composites by the pozzolanic effects and filling the pores, this leaded to reduction of permeability more than when SF is used.

L. Senff, et al [10] (2009) studied adding Amorphous nano-silica particles $(0-2.5 \mathrm{wt} \%)$ to cement pastes and mortars. They found that NS modified the characteristics of fresh mortars. The presence of NS decreased the amount of lubricating water available in the mixture and yield stress increases considerably.

A. Hakamy, et al [11] (2014) investigated the Characteristics of Hemp Fabric Reinforced Nano clay-Cement Nano composites; they found that, the optimum content of NC was $1 \%$. The HF-reinforced nano composites containing $1 \mathrm{wt} \% \mathrm{NC}$ decreased the porosity $(15.5 \%)$ and also increased the density (5.3\%), flexural strength (26.2\%) and fracture toughness $(24.9 \%)$. Adding more than 1\% NC to the HF-reinforced cement composites affects negatively the fracture toughness and the flexural strength.

K. Patel [12] (2012) studied the use of Nano clay aiming to constitute blended cement mortar with fractional increase in mechanical strength. They found the compressive strength was improved by $300 \%$ with $1 \%$ NC and by $290 \%$ with $2 \% \mathrm{NC}$ for seven day testing. At the age of 28 day the improvement reached $310 \%$ with $1 \% \mathrm{NC}$ and $200 \%$ with $2 \% \mathrm{NC}$.

M.S. Morsy, et al [13] (2010) studied the effect of Nano-clay on mechanical properties and microstructure of ordinary Portland cement mortar. NC was added with percentages of $0,2,4,6$ and $8 \%$ by weight of cement. The samples were first cured at $100 \%$ relative humidity for 24 hours and then cured in water for 28 days. The enhancement in compressive was $7 \%$ at $8 \% \mathrm{NC}$.

The purpose of this research is to study the effect of adding nano silica, nano clay and hybrid nanoparticles with different percentages to the cement paste to study their effect on compressive strength and drying shrinkage under different curing conditions.

\section{Experimental Work}

In this work the effect of adding different percentages of nanomaterials on the properties of cement pastes was examined under different curing conditions. 


\subsection{Materials.}

\subsection{1- Cement.}

Ordinary Portland cement (OPC) (CEM1 52.5 N) was used during the study, obtained from Beni-Suef Cement Factory in Egypt. The chemical analysis of the cement is shown in Table 1.

\subsubsection{Chemical Admixture.}

High performance superplasticizer (S.P) (Glenium ACE 30) was used which is an aqueous solution of modified Polycarboxylates, obtained from BASF Chemicals Company in Egypt.

\subsubsection{Nano Powders.}

Nano powders are two nano silica types (NS1 \& NS2) and nano clay.

\subsubsection{Nano Silica.}

The first type one of nano silica (NS1) is produced locally in nanomaterials laboratory on Beni-Suef University; it is characterized by $38 \mathrm{~nm}$ of the mean particle size and $110 \mathrm{~m}^{2} / \mathrm{g}$ of surface area, it consists of pure silica. Fig. 1. shows the Transmission Electron Microscope (TEM) micrograph of NS1 with magnification $200 \mathrm{k}$.

The second type two of nano silica (NS2) is imported from Sigma-Aldrich Company in Germany; it is characterized by $24 \mathrm{~nm}$ of the mean particle size and $220 \mathrm{~m}^{2} / \mathrm{g}$ of surface area, it consists of pure silica. Fig. 2. shows the TEM micrograph of NS2 with magnification $150 \mathrm{k} \mathrm{x}$.

\subsubsection{Nano Clay.}

Nano clay (NC) is montmorillonite clay $\left(\mathrm{OH}_{4} \mathrm{Si}_{8} \mathrm{AL}_{4} \mathrm{O}_{20} \mathrm{n}\right)$ was obtained from Middle East Mining Investments Company in Egypt (MEMCO) modified with quaternary ammonium salts (sodium calcium aluminum silicate) that is in crystalline state which is characterized by large length according to its thickness ratio. The nano clay used in this research was in an amorphous state. Thermal activation which was performed converted the nano clay crystalline state to amorphous state; it reduced the grain size of nano clay. The clay was exposed to $800^{\circ} \mathrm{C}$ temperature for two hours. The chemical and physical properties of NC are shown in Table 1. \& Table 2. respectively. Fig. 3. shows the TEM micrograph of NC with magnification $300 \mathrm{k}$. 


\subsection{Mix design and preparation of specimens.}

Standard cement paste was prepared according to ESS (2421-1993) [14] to determine the standard water - cement ratio, which was found in this study $20 \%$ for all mixes with S.P and $30 \%$ for mix M1 without S.P. superplasticizer changed from (1 to 1.5$) \%$ of cement to maintain the same water-cement ratio for all mixes.

\subsubsection{Mix design.}

Cement pastes were prepared, mixed, casted, cured and tested in the Material Laboratory in the Faculty of Engineering, Cairo University, nine cement paste mixes were designed and shown in table 3 , from which it can be noticed that mix M1 and M2 were control mixes with and without S.P, while mixes M3, M4 and M5 were with different percentages of nano silica( $1 \%, 3 \%)$, mixes M6 and M7 were with different percentages of nano clay $(5 \%, 7 \%)$, mixes M8 and M9 were with different percentages of hybrid nanomaterials $(5 \%, 6 \%)$ as weight percentage of cement content.

\subsubsection{Dispersion techniques of nanoparticles.}

To achieve perfect dispersion of nanoparticles to enhance the base matrix, two dispersion techniques are used in this study: a- Sonication, b- Stirring by vane motor.

\subsubsection{Sonication.}

Water bath sonicator shown in Fig. 4 has been used. Nanoparticles were mixed with half amount of the water and superplasticizer.

This technique was applied with nano silica and the period of sonication was 5 minutes, while it was 10 minutes when nano clay was used, the temperature was $40^{\circ} \mathrm{C}$. Table 4 . shows the specifications of water bath sonicator.

\subsubsection{Stirring by vane motor.}

The second technique of dispersion (Nanoparticles mixed with half amount of the water and super plasticizer) was dispersed by the vane motor shown in Fig. 5. the period was 2 minutes, until the mixture was homogeneous. Table 5. shows the specifications of vane motor. 


\subsubsection{Mixing Procedure.}

The cement and half amount of the water and SP needed for the mixture were mixed in a rotary mixer for thirty seconds. The ready mixed liquid (The other half of the water and SP amount and the nanoparticles) that resulted from the nano dispersion technique was added gradually and mixed for additional three minutes.

\subsubsection{Casting and Curing Procedure.}

The mixtures were casted in steel mold contains 30 cube of dimensions (20x $20 \times 20) \mathrm{mm}$ for compressive strength, and a mold contain 5 prisms of dimensions $(25 \times 25 \times 285) \mathrm{mm}$ was used for shrinkage measurements.

After one day from casting, samples have been demolded. There were two curing systems carried out: a- cured in tap water, b- uncured in open air. All these samples were tested after 3, 7 and 28 days.

\subsection{Testing Procedures.}

\subsubsection{The Compressive Strength.}

The compressive strength of cement paste cubes was determined using SHIMADZU $500 \mathrm{KN}$ Universal machine in Material laboratory in the Faculty of Engineering, Cairo University.

\subsubsection{The Drying Shrinkage.}

Drying shrinkage has been calculated according to references [15, 16], using the samples demolded from the prisms by measuring the change in their length using the Micrometer. The samples extracted from the prisms were $25 \times 25 \times 285 \mathrm{~mm}$ with two nails fixed at their two ends; the length between their internal edges was $250 \pm 2.5 \mathrm{~mm}$. After demolding the samples, the change in their length from the two edges of the nails has been measured (Lo). Then cured samples have been submerged in tap water for only forty eight hours, while uncured samples were left in the open air. After lifting the cured samples from the water, they have been left in the open air till the date of testing. Change of their length has been measured at ages: 3 , $7,14,21$ and 28 from the age of casting (Lf). Ages of measuring have been the same for the uncured samples (Lf).

The percentage of linear drying shrinkage (S\% ) was measured for each sample (cured and uncured) at each age as follows: 
$\mathrm{S} \%=\frac{\mathrm{Lo}-\mathrm{Lf}}{\mathrm{L}} \times 100 \%$,

where,

- $\mathrm{S} \%$ : Drying shrinkage strain.

- L: The effective length of the testing samples which is $250 \mathrm{~mm}$ according to [15].

- Lo: The length between the two nails edges after 24 hours.

- Lf: The length between the two nails edges at each age.

Table 1.

Chemical analysis of materials

\begin{tabular}{|c|c|c|c|c|}
\hline$\%$ & NC & NS2 & NS1 & CEM I 52.5 \\
\hline $\mathrm{SiO}_{2}$ & 19.8 & 99.1 & 99.1 & 61.24 \\
\hline $\mathrm{Al}_{2} \mathrm{O}_{3}$ & 5.5 & - & - & 20.89 \\
\hline $\mathrm{CaO}$ & 63 & - & - & 0.16 \\
\hline $\mathrm{MgO}$ & 1.2 & - & - & 0.22 \\
\hline $\mathrm{Fe}_{2} \mathrm{O}_{3}$ & 3.4 & - & - & 1.06 \\
\hline $\mathrm{Na}_{2} \mathrm{O}$ & 0.64 & - & - & 0.71 \\
\hline $\mathrm{K}_{2} \mathrm{O}$ & 0.19 & - & - & 1.61 \\
\hline $\mathrm{SO}_{3}$ & 3 & - & - & 0.17 \\
\hline $\mathrm{L}_{3} \mathrm{O} . \mathrm{I}$ & 2.5 & - & 13.12 \\
\hline
\end{tabular}

Table 2.

Physical properties of nanoparticles

\begin{tabular}{|c|c|c|c|c|}
\hline Nano Type & Colour & $\begin{array}{c}\text { BulkDensity } \\
\left(\mathbf{g} / \mathbf{c m}^{\mathbf{3}}\right)\end{array}$ & $\begin{array}{c}\text { Mean } \\
\text { Particle Size } \\
(\mathbf{n m})\end{array}$ & $\begin{array}{c}\text { Surface } \\
\text { Area } \\
\left(\mathbf{m}^{\mathbf{2}} / \mathbf{g}\right)\end{array}$ \\
\hline NS1 & White & 0.24 & 38 & 110 \\
\hline NS2 & White & 0.16 & 24 & 220 \\
\hline NC & Light Cream & 0.19 & 25 & 330 \\
\hline
\end{tabular}


Chemical analysis of materials

\begin{tabular}{|c|c|c|c|c|c|c|c|}
\hline Mix & Mix type & $\begin{array}{c}\text { Nano } \\
\text { Dispersion } \\
\text { Technique }\end{array}$ & $\begin{array}{c}\text { Cement } \\
\left.\mathbf{( K g} / \mathbf{m}^{3}\right)\end{array}$ & $\begin{array}{c}\text { Water } \\
\left(\mathbf{c m}^{3} / \mathbf{m}^{3}\right)\end{array}$ & $\begin{array}{c}\mathbf{S . P} \\
\left(\mathbf{c m}^{3} / \mathbf{m}^{3}\right)\end{array}$ & $\begin{array}{c}\text { Nano } \\
\mathbf{w e i g h t} \\
\left(\mathbf{K g} / \mathbf{m}^{3}\right)\end{array}$ & $\mathbf{W} / \mathbf{b}$ \\
\hline M1 & $\begin{array}{c}\text { Control } \\
\text { without S.P }\end{array}$ & - & 2250 & 675 & - & - & 0.3 \\
\hline M2 & $\begin{array}{c}\text { Control } \\
\text { with S.P }\end{array}$ & - & 2250 & 450 & $1 \%=22.5$ & - & 0.2 \\
\hline M3 & $1 \%$ NS1 & Stirring & 2227.5 & 450 & $1.25 \%=28.125$ & 22.5 & 0.2 \\
\hline M4 & $3 \%$ NS1 & Stirring & 2182.5 & 450 & $1.25 \%=28.125$ & 67.5 & 0.2 \\
\hline M5 & $1 \%$ NS2 & Sonication & 2227.5 & 450 & $1.25 \%=28.125$ & 22.5 & 0.2 \\
\hline M6 & $5 \%$ NC & Sonication & 2137.5 & 450 & $1.25 \%=28.125$ & 112.5 & 0.2 \\
\hline M7 & $7 \%$ NC & Sonication & 2092.5 & 450 & $1.5 \%=33.75$ & 157.5 & 0.2 \\
\hline M8 & $\begin{array}{c}0.5 \% \text { NS1 \& } \\
4.5 \% \text { NC } \\
(5 \% \text { Hybrid })\end{array}$ & $\begin{array}{c}\text { Stirring for NS1 } \\
\& \text { Sonication } \\
\text { for NC }\end{array}$ & 2137.5 & 450 & $1.5 \%=28.125$ & $\begin{array}{c}\text { NS1 }=11.25 \\
\text { NC }=101.25\end{array}$ & 0.2 \\
\hline M9 & $\begin{array}{c}1 \% \text { NS1 \& } \\
5 \% \text { NC } \\
(6 \% \text { Hybrid })\end{array}$ & $\begin{array}{c}\text { Stirring for NS1 } \\
\& \text { Sonication } \\
\text { for NC }\end{array}$ & 2115 & 450 & $1.5 \%=28.125$ & $\begin{array}{c}\text { NS1 }=22.5 \\
\text { NC }=112.5\end{array}$ & 0.2 \\
\hline
\end{tabular}

Table 4.

\section{Specifications of water bath sonicator}

\begin{tabular}{|c|c|}
\hline Volume (L) & 6 \\
\hline Power supply (V) & 220 \\
\hline Frequency (Hz) & 50 \\
\hline Power consumption (watt) & 200 \\
\hline Timer (Minute) & $1-30$ \\
\hline
\end{tabular}

\section{Specifications of vane motor}

\begin{tabular}{|c|c|}
\hline Speed range (rpm) & $1500-2800$ \\
\hline Frequency (Hz) & 50 \\
\hline Power consumption (watt) & 600 \\
\hline
\end{tabular}


THE RESULTS OF THE SPECIALISTS' AND SCIENTISTS' RESEARCHES

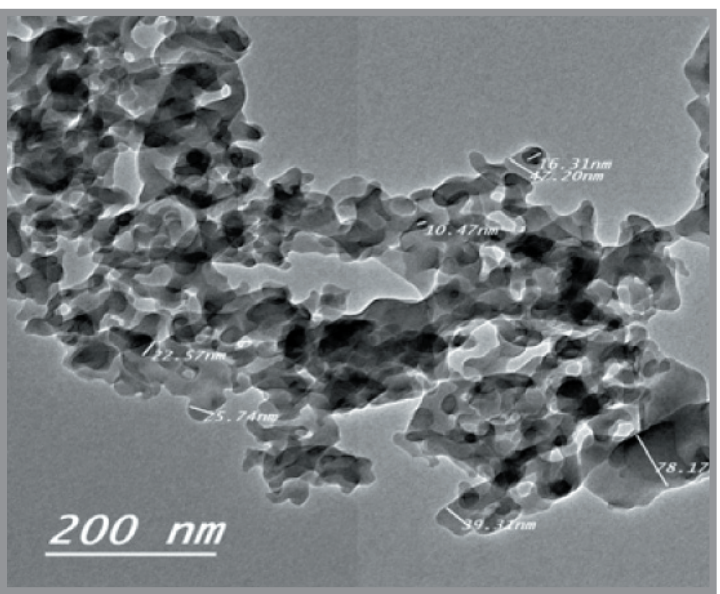

Fig. 1. TEM micrograph of NS1

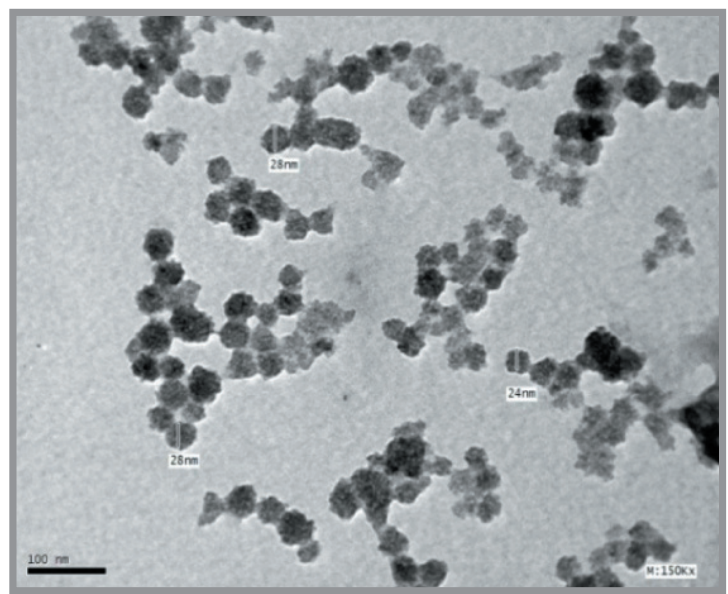

Fig. 2. TEM micrograph of NS2

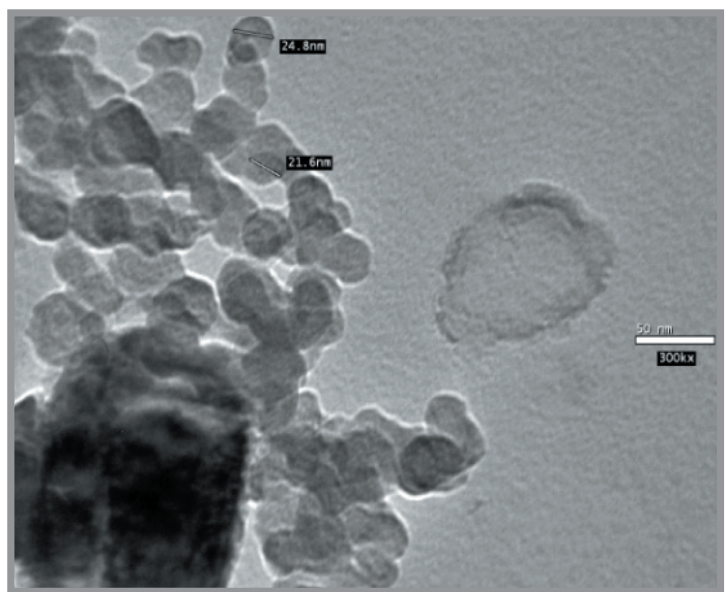

Fig. 3. TEM micrograph of NC

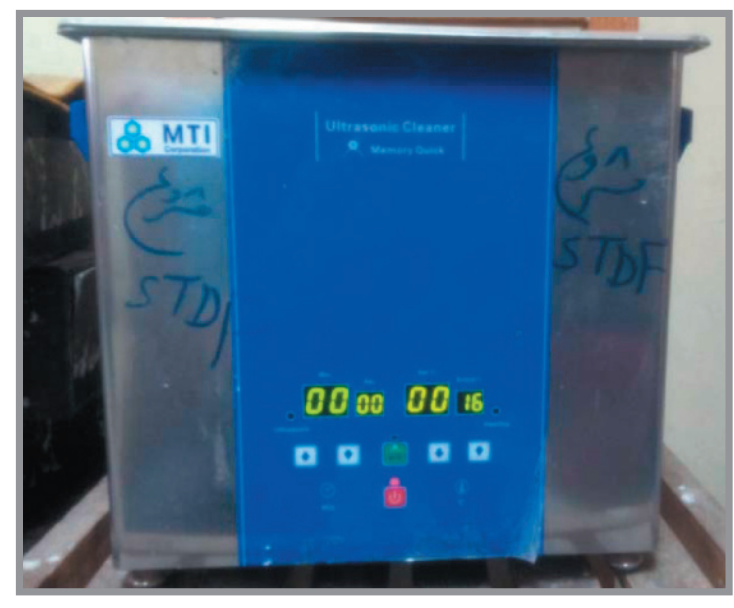

Fig. 4. Water bath sonicator

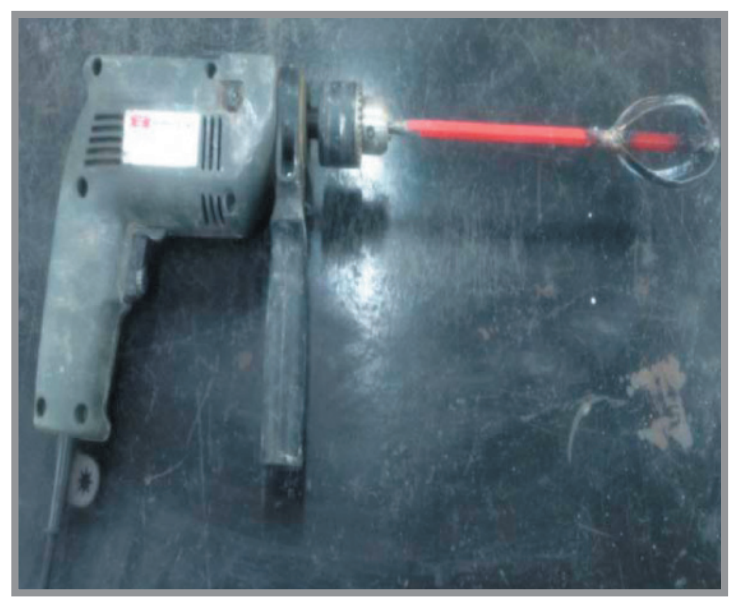

Fig. 5. Vane motor 
At each age, the average of the drying shrinkage percentage ( $\mathrm{S} \%$ ) has been calculated for the six (cured and uncured) samples, in addition to measuring humidity and temperature.

\section{Analysis and Discussion of Test Results}

Table 6. shows the compressive strength test results of cement paste mixtures with and without nanoparticles at the ages of 7, 14 and 28 days for both cured and uncured mixtures, and drying shrinkage test results with and without nanoparticles at the ages of $3,7,14,21$ and 28 days.

Table 6 .

\section{Compressive strength and drying shrinkage of cement paste samples with and without nanoparticles}

\begin{tabular}{|c|c|c|c|c|c|c|c|c|c|c|c|}
\hline \multirow{2}{*}{ Mix } & \multirow{2}{*}{$\begin{array}{l}\text { Mix } \\
\text { Descrip- } \\
\text { tion }\end{array}$} & \multirow{2}{*}{$\begin{array}{c}\text { Nano } \\
\text { Mixing } \\
\text { Procedure }\end{array}$} & \multicolumn{3}{|c|}{$\begin{array}{c}\text { Compressive Strength } \\
\text { (MPa) }\end{array}$} & \multicolumn{5}{|c|}{ Drying Shrinkage (S\%) } & \multirow{2}{*}{$\begin{array}{c}\text { Curing } \\
\text { Condi- } \\
\text { tions }\end{array}$} \\
\hline & & & 7 days & $\begin{array}{c}14 \\
\text { days }\end{array}$ & $\begin{array}{c}28 \\
\text { days }\end{array}$ & 3 days & 7 days & $\begin{array}{c}14 \\
\text { days }\end{array}$ & $\begin{array}{c}21 \\
\text { days }\end{array}$ & $\begin{array}{c}28 \\
\text { days }\end{array}$ & \\
\hline \multirow{2}{*}{ M1 } & \multirow{2}{*}{$\begin{array}{c}\text { Control } \\
\text { without SP }\end{array}$} & & 57.50 & 71.63 & 73.80 & -.0294 & 0.0176 & .0676 & 0.1118 & 0.1196 & Cured \\
\hline & & & 29.28 & 41.00 & 43.70 & 0.0471 & 0.0824 & 0.1026 & 0.1444 & 0.1451 & Uncured \\
\hline \multirow{2}{*}{ M2 } & \multirow{2}{*}{$\begin{array}{l}\text { Control } \\
\text { with SP }\end{array}$} & \multirow{2}{*}{ - } & 83.75 & 106.50 & 112.50 & -.0209 & 0.0046 & .0431 & 0.0732 & 0.0745 & Cured \\
\hline & & & 67.50 & 80.00 & 97.25 & 0.0275 & 0.0431 & 0.0752 & 0.0869 & 0.0908 & Uncured \\
\hline \multirow{2}{*}{ M3 } & \multirow{2}{*}{$1 \% \mathrm{NS} 1$} & \multirow{2}{*}{ Stirring } & 85.00 & 110.63 & 125.81 & -.0176 & 0.0327 & 0.0712 & 0.0758 & 0.0967 & Cured \\
\hline & & & 68.75 & 75.50 & 83.38 & 0.0431 & 0.0608 & 0.0941 & 0.1078 & 0.1324 & Uncured \\
\hline \multirow{2}{*}{ M4 } & \multirow{2}{*}{$3 \% \mathrm{NS} 1$} & \multirow{2}{*}{ Stirring } & 66.25 & 70.75 & 87.00 & -.0157 & 0.0333 & 0.0647 & 0.0765 & 0.1026 & Cured \\
\hline & & & 61.63 & 67.25 & 80.00 & 0.0461 & 0.0696 & 0.0995 & 0.1137 & 0.1402 & Uncured \\
\hline \multirow{2}{*}{ M5 } & \multirow{2}{*}{$1 \% \mathrm{NS} 2$} & \multirow{2}{*}{ Sonication } & 91.00 & 118.00 & 131.00 & -.0163 & 0.0203 & 0.0490 & 0.0758 & 0.0863 & Cured \\
\hline & & & 85.00 & 109.00 & 117.00 & 0.0327 & 0.0490 & 0.0797 & 0.0915 & 0.1026 & Uncured \\
\hline \multirow{2}{*}{ M6 } & \multirow{2}{*}{$5 \% \mathrm{NC}$} & \multirow{2}{*}{ Sonication } & 85.00 & 117.75 & 126.06 & -.0176 & 0.0072 & 0.0366 & 0.0392 & 0.0441 & Cured \\
\hline & & & 68.75 & 73.13 & 95.63 & 0.0157 & 0.0281 & 0.0523 & 0.0536 & 0.0549 & Uncured \\
\hline \multirow{2}{*}{ M7 } & \multirow{2}{*}{$7 \% \mathrm{NC}$} & \multirow{2}{*}{ Sonication } & 71.50 & 86.25 & 103.50 & -.0147 & 0.0098 & 0.0402 & 0.0422 & 0.0471 & Cured \\
\hline & & & 63.13 & 70.63 & 81.50 & 0.0170 & 0.0294 & 0.0569 & 0.0580 & 0.0624 & Uncured \\
\hline \multirow{2}{*}{ M8 } & \multirow{2}{*}{$5 \%$ Hybrid } & \multirow{2}{*}{$\begin{array}{l}\text { Stirring for } \\
\text { NS1 \& Sonica- } \\
\text { tion for NC }\end{array}$} & 88.25 & 115.25 & 129.00 & -.0196 & 0.0216 & 0.0490 & 0.0740 & 0.0761 & Cured \\
\hline & & & 80.25 & 90.50 & 96.25 & 0.0275 & 0.0471 & 0.0772 & 0.0882 & 0.0922 & Uncured \\
\hline \multirow{2}{*}{ M9 } & \multirow{2}{*}{ 6\% Hybrid } & \multirow{2}{*}{$\begin{array}{l}\text { Stirring for } \\
\text { NS1 \& Sonica- } \\
\text { tion for NC }\end{array}$} & 83.00 & 106.13 & 111.25 & -.0197 & 0.0275 & 0.0569 & 0.0750 & 0.0784 & Cured \\
\hline & & & 73.00 & 81.00 & 87.50 & 0.0314 & 0.0627 & 0.0863 & 0.0980 & 0.1059 & Uncured \\
\hline
\end{tabular}




\subsection{Compressive strength.}

\subsubsection{The effect of addition superplasticizer (S.P) on compressive strength.}

Fig. 6. shows that when S.P was added to the cement paste, the enhancement in the workability and compressive strength at all ages was clear in the cured and uncured samples compared to the mixtures without S.P. this can be attributed to the reduction in water cement ratio. The percent of improvement in compressive strength for control cured and uncured mortar mixture with S.P are $52.5 \%$ and $122.6 \%$ respectively at 28 days compared to control mixes.

\subsubsection{The effect of adding NS1 and NS2 on compressive strength.}

Fig. 7. shows the development of compressive strength for control cement paste mixes with S.P and mixes with different percentages of nano silica, it can be seen that the addition of $1 \%$ NS1- locally produced - using stirring dispersion technique to mixes increased the compressive strength compared to control ones for cured samples at all ages, the improved percentages of compressive strength reached $1.49 \%, 3.88 \%$, and $11.83 \%$ at 7,14 , and 28 days respectively, while the uncured samples with $1 \%$ NS1 showed a decrease in the compressive strength compared to the uncured control mixture with S.P.

The increase in the compressive strength can be attributed to the efficiency of nanoparticles in promoting pozzolanic reaction, packing the voids and consuming calcium hydroxide crystals forming additional calcium silicate hydrate $(\mathrm{C}-\mathrm{S}-\mathrm{H})$.

When the NS1 percentage was increased to 3\%, using stirring dispersion technique, there was a decrease in the compressive strength at all ages for the cured and uncured samples compared to the control mixture.

This means, there is a certain limit after which any increase in the NS percentage leads to a decrease in the compressive strength, this can be attributed to the agglomeration caused by the nano silica particles when adding excessive amount as the high surface area increases attracting these particles to each other forming weak clogs, these clogs fill the voids of the cement paste mixture preventing the filling effect of nanoparticles decreasing the mixture strength. The other possible explanation is that the mixing water is not enough to coat this large percentage of the nano silica particles causing defects in the hydration process decreasing compressive strength, 
thus mixing with $3 \%$ NS1 needs more percentage of S.P compared to control mixture in order to enhance workability.

As a result of adding 1\% NS1 to mixture which is the optimum percentage, this percentage has been applied for NS2 particles -imported- to mixture using sonication dispersion technique. Fig. 7. also shows that the

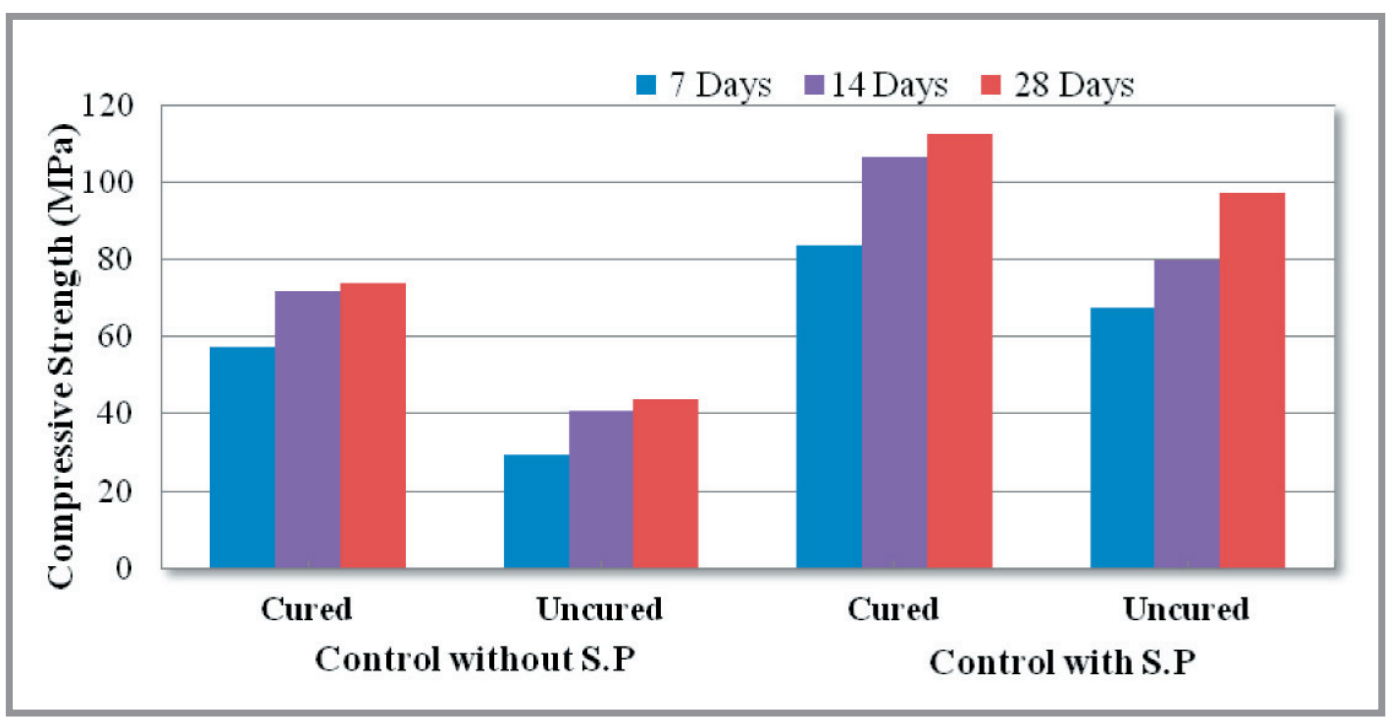

Fig. 6. Development of compressive strength for control cement paste mixes with and without S.P at different ages

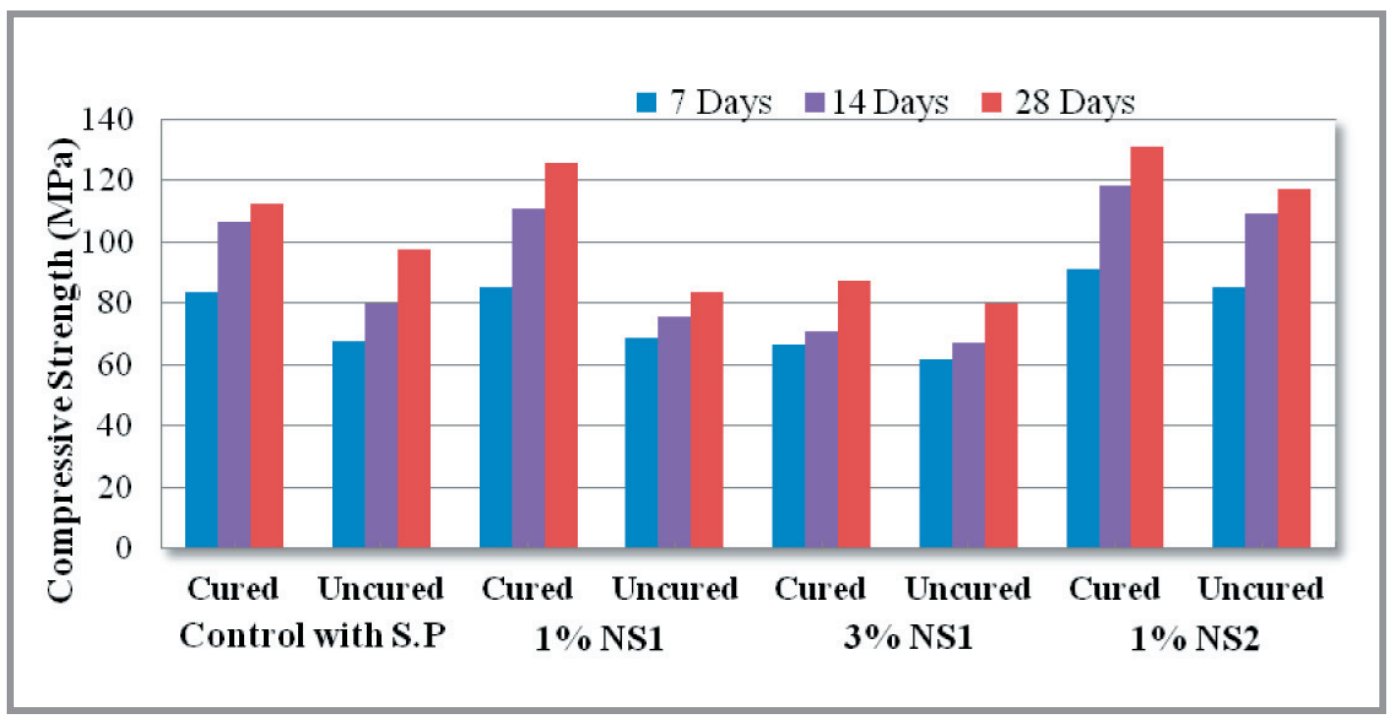

Fig. 7. Development of compressive strength for control cement paste mixes with S.P and mixes with different percentages of nano silica 
addition of $1 \%$ NS2 to mixes increased the compressive strength compared to control ones for cured and uncured samples at all ages.

It can be concluded that the best percentage of NS1 and NS2 is 1\%, using stirring and sonication dispersion techniques respectively for cured samples, while the uncured samples of $1 \% \mathrm{NS} 2$ is higher compared to the uncured and cured control mixtures.

\subsubsection{The effect of adding NC on compressive strength.}

Fig. 8. shows the development of compressive strength for control cement paste mixes with S.P and mixes with different percentages of nano clay, it can be seen that the addition of $5 \% \mathrm{NC}$ using sonication dispersion technique to mixes increased the compressive strength compared to control ones for cured samples at all ages, the improved percentages of compressive strength reached $1.49 \%, 10.56 \%$, and $12.06 \%$ at 7,14 , and 28 days respectively, While the uncured samples with $5 \%$ NC showed a decrease in the compressive strength compared to the uncured control mixture.

The increase in the compressive strength can be attributed to a- the efficiency of nanoparticles in promoting pozzolanic reaction, packing the voids and consuming calcium hydroxide forming additional calcium silicate hydrate $(\mathrm{C}-\mathrm{S}-\mathrm{H}) \mathrm{b}$ - the effect of nano clay which behaves as a filler that improves the microstructure, and as a self curing action when it is mixed into cement, and after it is hardened, nano clay will slowly release this water to an unhydrated cement during the critical early conditions of curing, assisting in more complete hydration of cement.

Fig. 8 also shows that, by raising the NC percentage to reach $7 \%$ using sonication dispersion technique, there was a decrease in the compressive strength at all ages for the cured and uncured samples compared to the control mixture; this is due to the same reasons mentioned before when adding excess amounts of NS1 mixtures.

\subsubsection{The effect of adding Hybrid nanomaterials on compressive strength.}

Fig. 9 shows the development of compressive strength for control cement paste mixes with S.P and mixes with different percentages of hybrid nanomaterials, using suitable dispersion technique for each nano particle, it can be seen that the addition of $5 \%$ Hybrid to mixes increased the com- 


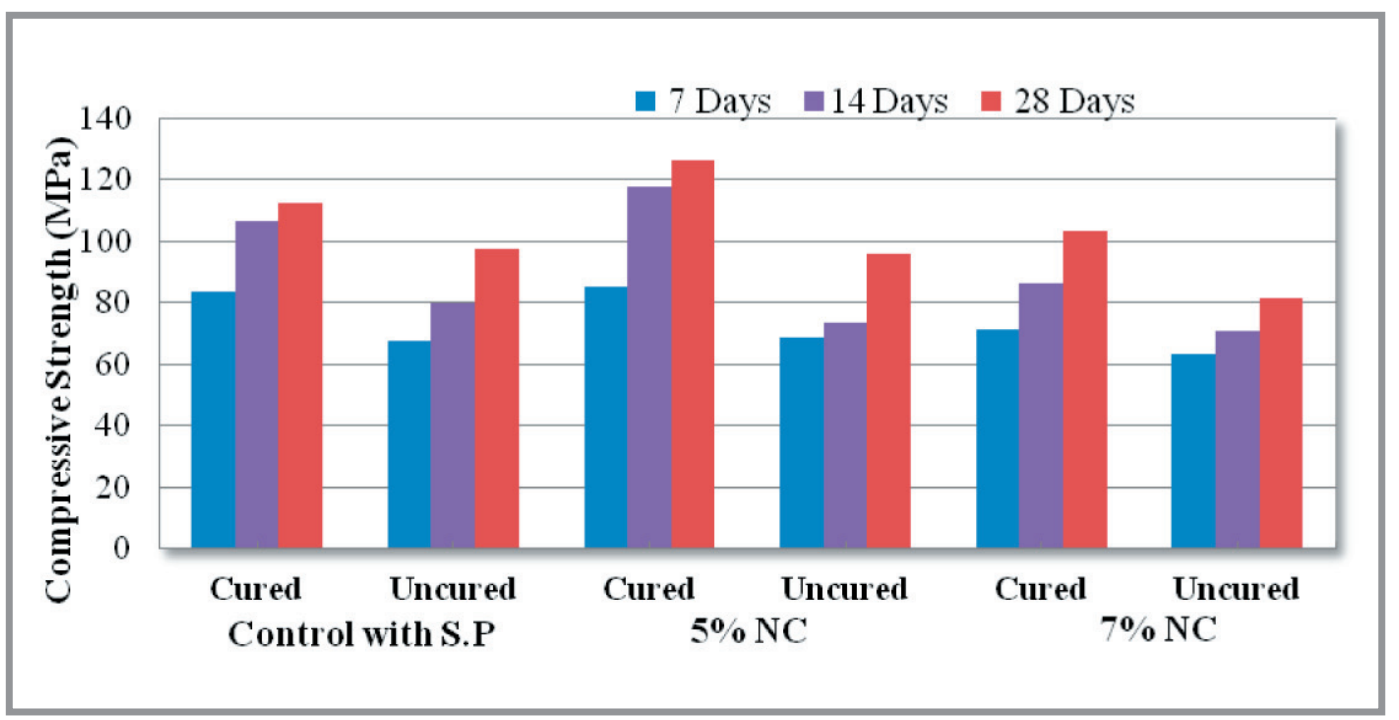

Fig. 8. Development of compressive strength for control cement paste mixes with S.P and mixes with different percentages of nano clay

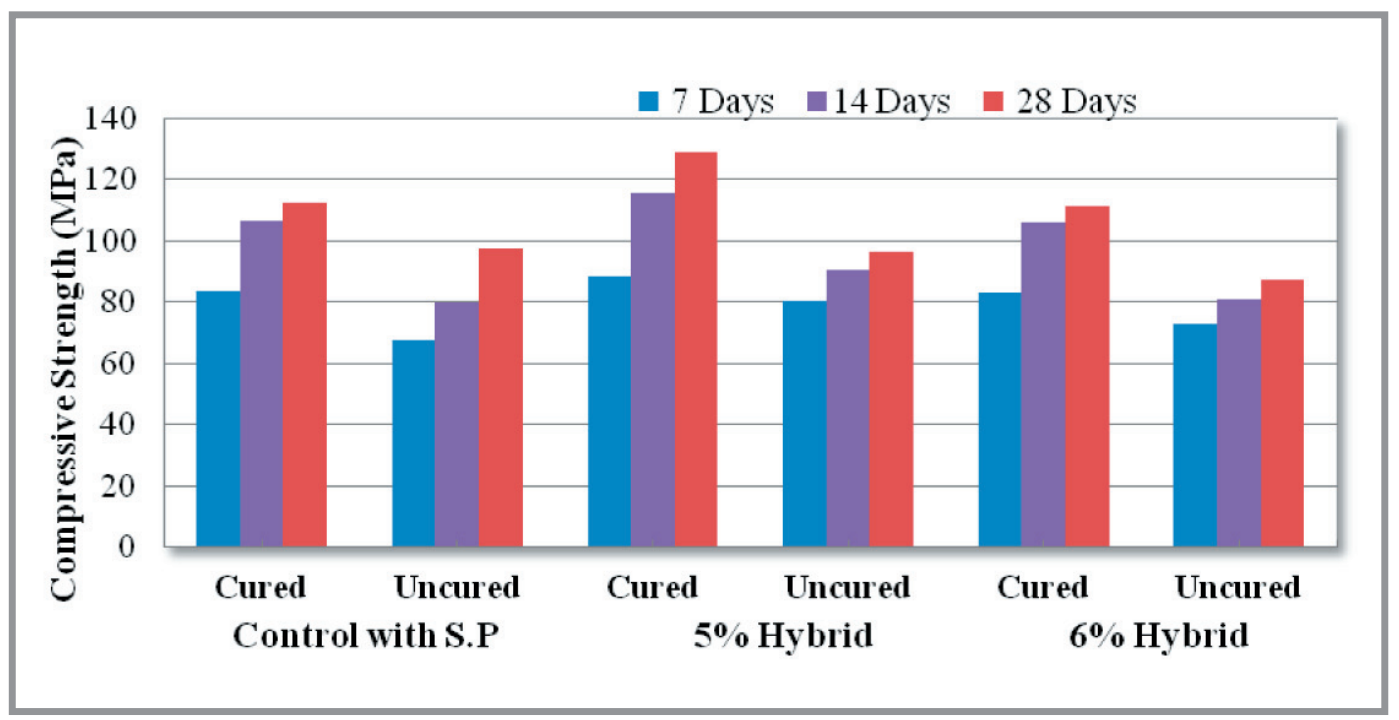

Fig. 9. Development of compressive strength for control cement paste mixes with S.P and mixes with different percentages of hybrid nanomaterials

pressive strength compared to control ones for cured samples at all ages, the improved percentages of compressive strength reached $5.4 \%, 8.23 \% \%$, and $14.67 \%$ at 7,14 , and 28 days respectively, while the uncured samples with $5 \%$ Hybrid showed a slight increase in the compressive strength compared to the uncured control mixture. 
The increase in the compressive strength can be attributed to a- the efficiency of nano silica and clay in promoting pozzolanic reaction, packing the voids and consuming calcium hydroxide forming additional calcium silicate hydrate $(\mathrm{C}-\mathrm{S}-\mathrm{H}) \mathrm{b}$ - the effect of nano clay alone behaves as a filler that improves the microstructure, and as a self curing action when it is mixed into cement, and after it is hardened, nano clay will slowly release this water to an unhydrated cement during the critical early conditions of curing, assisting in more complete hydration of cement.

Fig. 9. also shows that, when the hybrid nanomaterials percentage was increased to $6 \%$, there was a decrease in the compressive strength at all ages for the cured and uncured samples compared to the control mixture; this is due to the same reasons mentioned before when adding excess amounts of NS1 mixtures.

\subsection{Drying Shrinkage.}

In the procedures of measuring drying shrinkage, temperature and humidity were measured at each age as shown in Fig. 10 and 11 respectively.

\subsubsection{The effect of addition superplastisizer (S.P) on drying shrinkage.}

Fig. 12 shows that, when S.P was added to the cement paste, as a result of decreasing the water cement ratio, the compressive strength of the mixture was enhanced and the drying shrinkage decreased at all ages in the cured and uncured conditions compared to the mixtures without S.P. The percent of decreasing in drying shrinkage for control cured and uncured mortar mixture with S.P are $37.8 \%$ and $37.4 \%$ respectively at 28 days.

\subsubsection{The effect of adding NS1 and NS2 on drying shrinkage.}

Fig. 13 shows the development of drying shrinkage for control cement paste mixes with S.P and mixes with different percentages of nano silica, it can be seen that the addition of 1\% NS1 using stirring dispersion technique to mixes increased the drying shrinkage compared to control ones for cured and uncured samples at all ages. Thus, hydration of cement accelerated for nano silica which acts as an activator, so the shrinkage increased.

When raising the NS1 percentage to reach 3\%, using stirring dispersion technique, there was an increase in the drying shrinkage for cured and uncured samples at all ages compared to mixes with 1\% NS1 using stirring method. This can be attributed to that the rate of hydration is directly pro- 


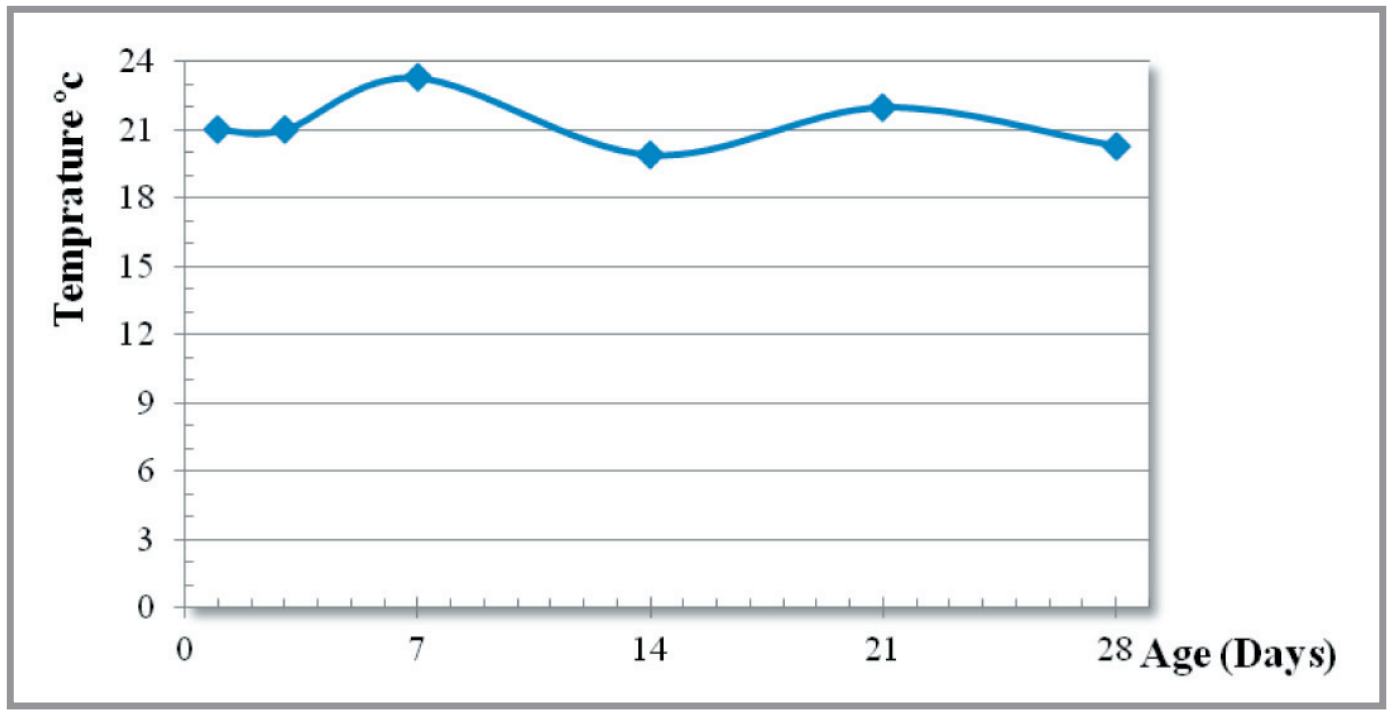

Fig. 10. Variation of temperature during the age of testing drying shrinkage

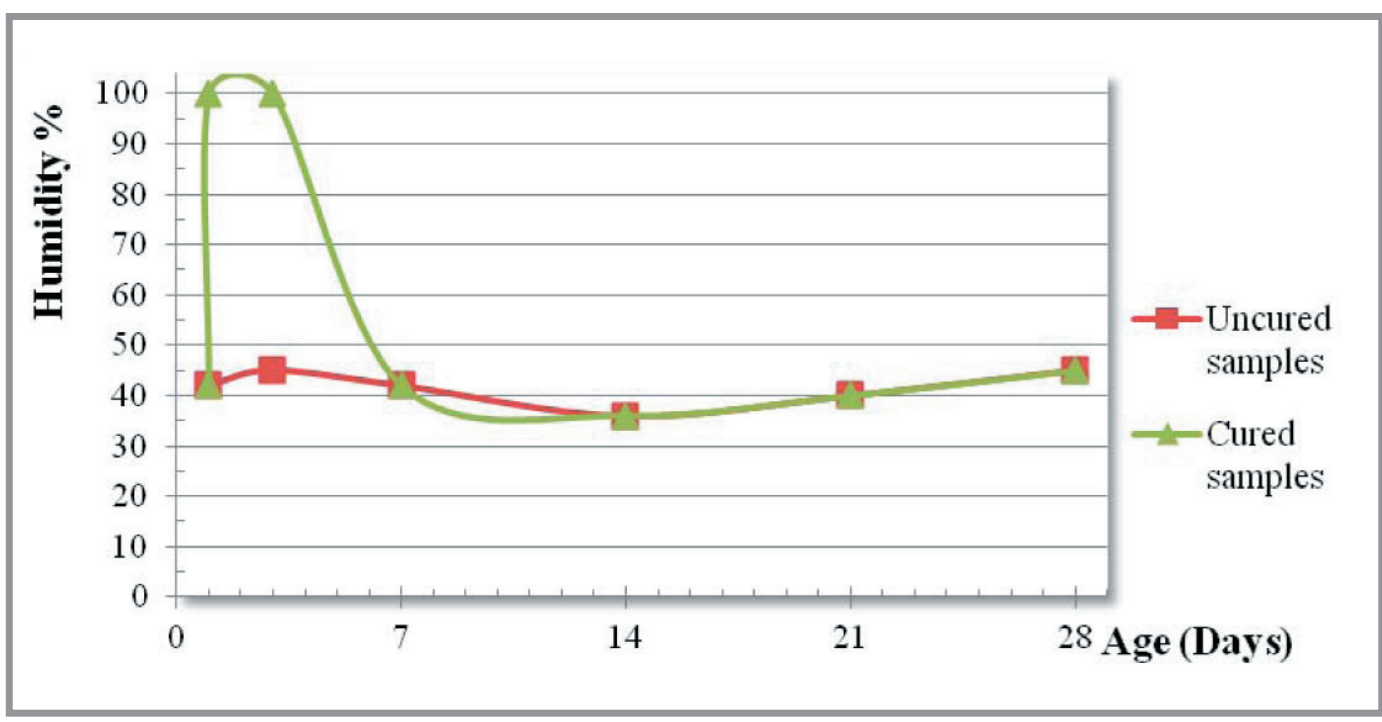

Fig. 11. Variation of humidity during the age of testing drying shrinkage for cured and uncured samples

portional to the percentage of nano silica, the heat emitted from hydration increases the evaporation leading to higher rates of drying shrinkage.

Fig. 13 also shows that the addition of $1 \%$ NS2 using sonication dispersion technique to mixes increased the drying shrinkage compared to control ones for cured and uncured samples at all ages; this is due to the same reason mentioned before in 1\% NS1 mixes. 


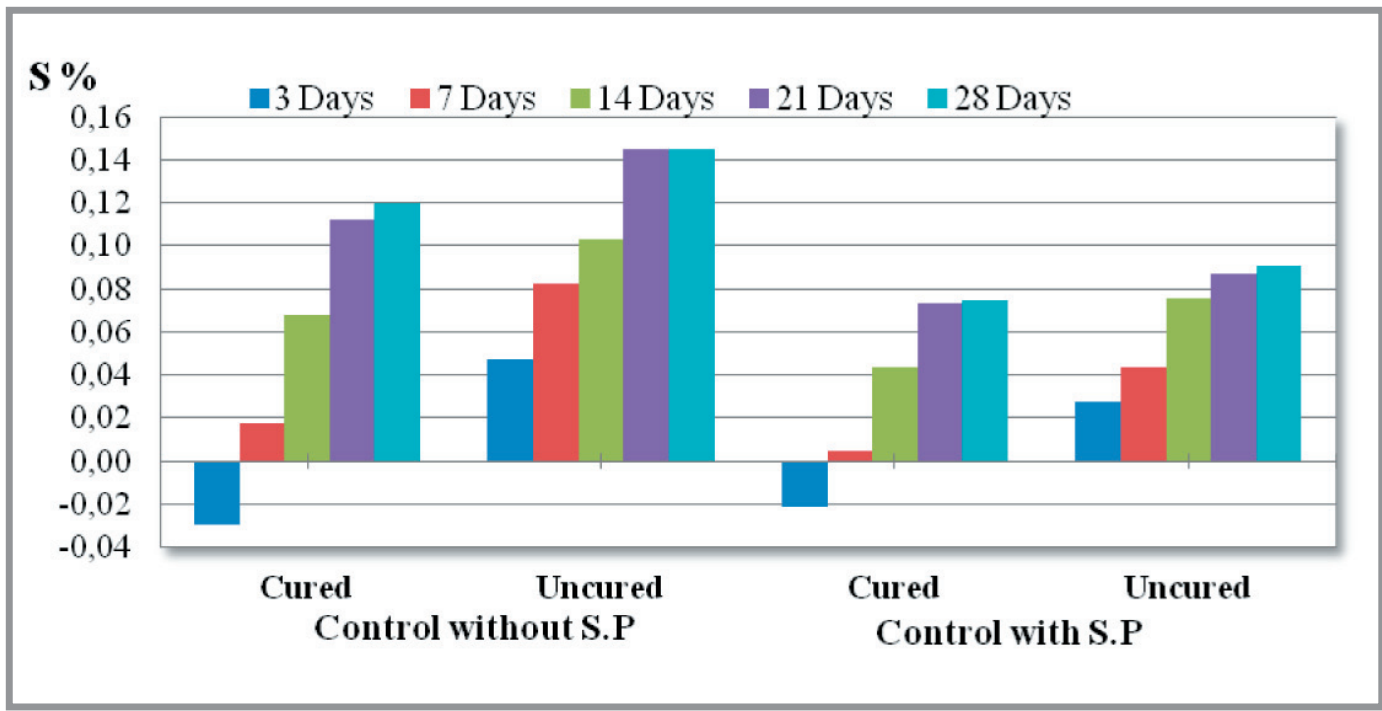

Fig. 12. Development of drying shrinkage for control cement paste mixes with and without S.P at different ages

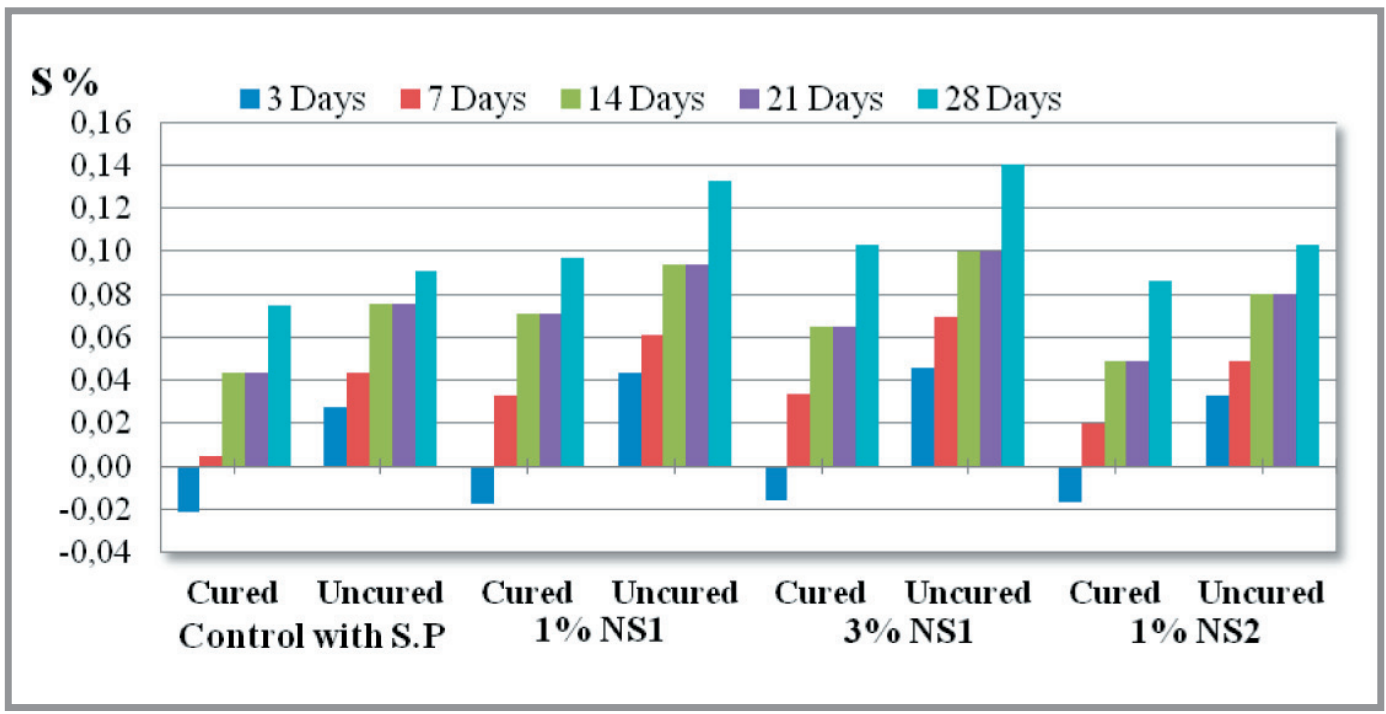

Fig. 13. Development of drying shrinkage for control cement paste mixes with and S.P and mixes with different percentages of nano silica

\subsubsection{The effect of adding NC on drying shrinkage.}

Fig. 14 shows the development of drying shrinkage for control cement paste mixes with S.P and mixes with different percentages of nano clay, it can be seen that the addition of $5 \% \mathrm{NC}$ using sonication dispersion tech- 
nique to mixes decreased the drying shrinkage compared to control ones for cured and uncured samples at all ages.

This is can be attributed to the effect of nano clay which behaves as a filler that improves the microstructure, and as a self curing action when it is mixed into cement, and after it is hardened, nano clay will slowly release this water to an unhydrated cement during the critical early conditions of curing, assisting in more complete hydration of cement which contributes to decreasing drying shrinkage.

When NC was increased to $7 \%$ using sonication dispersion technique, there was a decrease in the drying shrinkage for cured and uncured samples at all ages compared to control mixtures and an increase compared to mixes with $5 \%$ NC.

When adding excessive amount of NC as the high surface area increases, this attracts these particles to each other forming weak clogs. These clogs fill the voids of the cement paste mixture preventing the filling effect of nanoparticles leading to less decreasing in shrinkage.

\subsubsection{The effect of adding Hybrid nanomaterials on drying shrinkage.}

Fig. 15 shows the development of drying shrinkage for control cement paste mixes with S.P and mixes with different percentages of Hybrid nanomaterials using suitable dispersion technique for each nano particle, it can be seen that the addition of 5\% Hybrid nanomaterials to mixes increased the drying shrinkage compared to control ones for cured and uncured samples at all ages.

When the Hybrid nanomaterials percentage was increased to $6 \%$, there was an increase in the drying shrinkage for cured and uncured samples at all ages compared to mixes with $5 \%$ Hybrid.

This can be attributed to that the increase in drying shrinkage of NS1 overcomes the decrease in drying shrinkage of NC in hybrid mixtures, but hybrid mixtures were not higher than NS1 mixtures in shrinkage results.

\subsection{Effect of dispersion techniques.}

Sonication and stirring were the two dispersion techniques that had been used to reach well dispersion for nanoparticles in this study. From compressive strength test results, sonication was the efficient technique when the nano particle size is less than $30 \mathrm{~nm}$ and its bulk density is less 


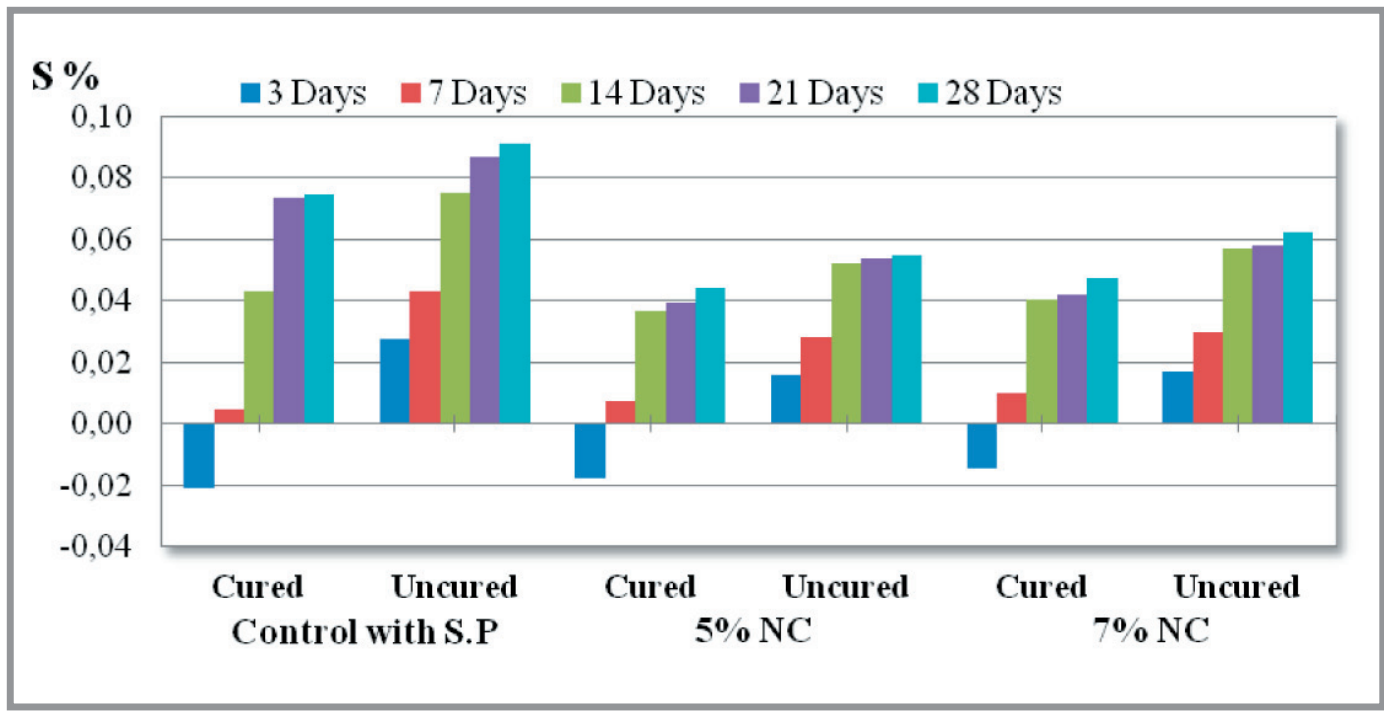

Fig. 14. Development of drying shrinkage for control cement paste mixes with and S.P and mixes with different percentages of nano clay

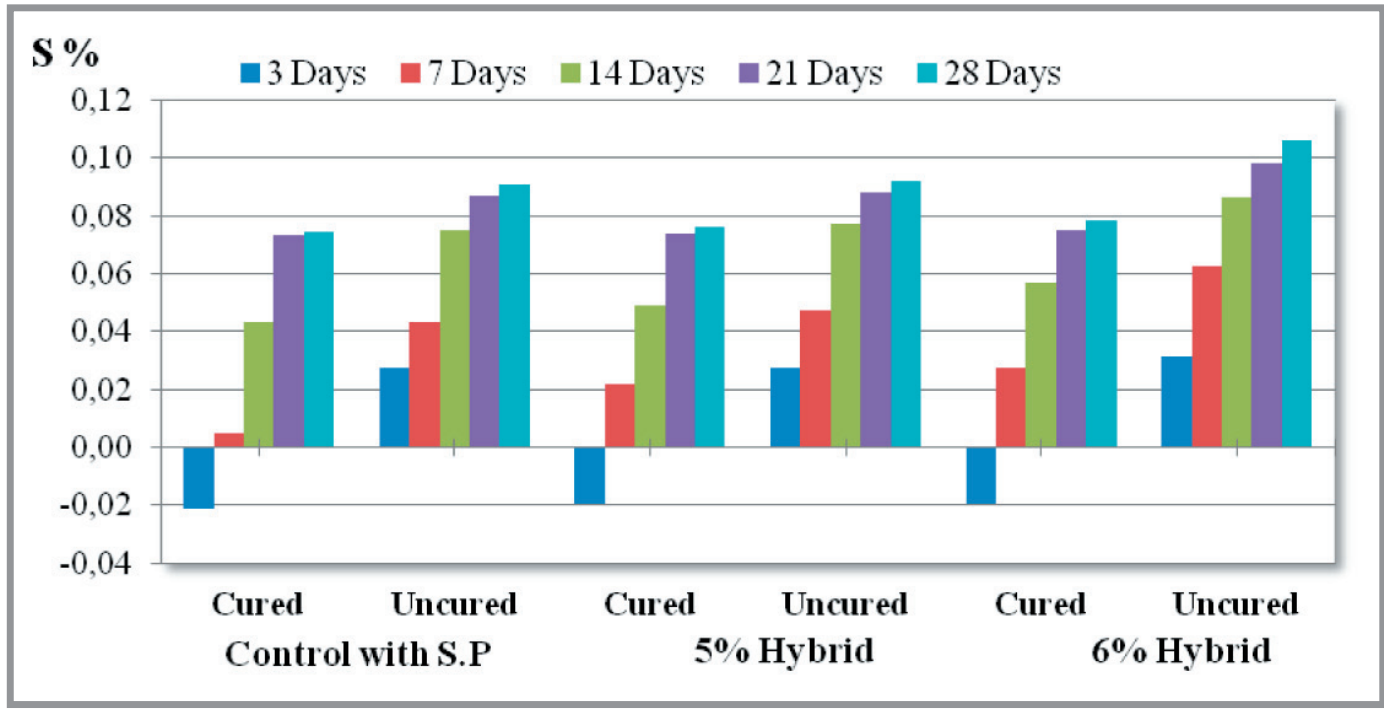

Fig. 15. Development of drying shrinkage for control cement paste mixes with and S.P and mixes with different percentages of hybrid nanomaterials

than $0.2 \mathrm{~g} / \mathrm{cm}^{3}$ as in the imported nano silica (NS2) and nano clay (NC). Stirring was the suitable technique when the physical properties changed by increasing the particle size more than $30 \mathrm{~nm}$ and bulk density more than $0.2 \mathrm{~g} / \mathrm{cm}^{3}$ of nanomaterial as in the local nano silica (NS1). In all cases the particle size did not exceed $100 \mathrm{~nm}$. 


\subsection{Effect of curing conditions.}

From compressive strength results, cured condition was effective with all types of used nanoparticles on mixes which enhanced the rate of hydration. Uncured condition was only effective with imported nano silica (NS2) compared to the cured and uncured control mixture as presented in Fig. 7. This can be attributed to the small particle size of NS2 which fills the voids that enables the mix to maintain some of the mixing water. The reason of studying the uncured condition is to evaluate its acceptability when using nanomaterials.

\section{CONCLUSIONS}

- The nanoparticles improve the features of the mixtures by promoting pozzolanic reaction, packing the voids, in addition to consuming calcium hydroxide crystals forming additional calcium silicate hydrate $(\mathrm{C}-\mathrm{S}-\mathrm{H})$ which participate in increasing strength. This can only be achieved by using suitable dispersion technique that results in well dispersion.

- Nanoparticles improve the mechanical properties at certain percentages. When there is an excessive amount, the particles form weak clogs as a result of the high surface area or the increase in the mixing water demand so it won't be able to enhance the hydration process forming $\mathrm{C}-\mathrm{S}-\mathrm{H}$.

- Applying Nanoparticles with S.P improved the strength and shrinkage of the mixes because the nanoparticles interpenetrate polymer network causing the above improvements.

- Cured condition was effective with all types of used nanoparticles, since it enhanced the rate of hydration. While uncured condition was only effective with imported nano silica (NS2) compared to the cured and uncured control mixture because of the small nano particle size of NS2 which fills the voids that enables the mix to maintain some of the mixing water.

- The optimum percentage of NS1 in the compressive strength test was $1 \%$ using stirring dispersion technique, the improvement were $11.83 \%$ for cured mixes at 28 days compared to control cured samples.

- The optimum percentage of NS2 in the compressive strength test was $1 \%$ using sonication dispersion technique, the improvement was 
$16.45 \%$ and $4 \%$ for cured and uncured mixes respectively at 28 days compared to control cured samples.

- The optimum percentage of NC in the compressive strength test was $5 \%$ using sonication dispersion technique, the improvement was $12.06 \%$ for cured mixes at 28 days compared to control cured samples.

- The optimum percentage of hybrid nanomaterials in the compressive strength test was $5 \%(0.5 \% \mathrm{NS} 1 \& 4.5 \% \mathrm{NC})$ with using the suitable dispersion technique for each nano particle, the improvement was $14.7 \%$ for cured mixes at 28 days compared to control cured samples.

- The drying shrinkage decreases in the cured and uncured conditions with adding nano clay in the cement paste mixtures compared to the control ones. This can be attributed to the effect of self curing action of $\mathrm{NC}$ when it is mixed into cement, and after it is hardened, nano clay will slowly release this water to unhydrated cement during the critical early phases of curing which assist in more complete hydration of cement which contributes to increase compressive strength and decrease drying shrinkage.

- The drying shrinkage increases in the cured and uncured conditions with adding nano silica and hybrid nanomaterials in cement paste mixtures compared to control ones due to the acceleration of hydration of cement, since nano silica acts as an activator, so the drying shrinkage increased. In hybrid mixtures, the increase in drying shrinkage of NS1 overcomes the decrease in drying shrinkage of NC.

\section{DeAR COlleagues!}

THE REFERENCE TO THIS PAPER HAS THE FOLLOWING CITATION FORMAT:

Zaki Saaid I., Hossam A. Hodhod, Mostafa A. Mahdi. The effect of using hybrid nano materials on drying shrinkage and strength of cement pastes. Nanotehnologii v stroitel'stve $=$ Nanotechnologies in Construction. 2016, Vol. 8, no. 2, pp. 109134. DOI: dx.doi.org/10.15828/2075-8545-2016-8-2-109-134. 


\section{References:}

1. Mahdi M.A. The Effect of Using Nano Materials on the Properties of Cement Paste and Mortar. M.Sc Thesis on Structural Department, Faculty of Engineering, Cairo University, Egypt, September 2015.

2. Mohamed A.M. Influence of Nano Materials on Flexural Behavior and Compressive Strength of Concrete. HBRC Journal, November 2014.

3. Sobhy I. Effect of Using Nano- Silica Particles on the Properties of Different Concrete Mixes. MSc. Thesis, Civil Department, Faculty of Engineering, Helwan University, Egypt 2012.

4. Morsy M.S., Alsayed S.H., Aqel M. Hybrid Effect of Carbon Nanotube and NanoClay on Physico-Mechanical Properties of Cement Mortar. Construction and Building Materials, 25 (2011), PP (145-149).

5. Yang $H$. Strength and Shrinkage Property of Nano Silica Powder Concrete. Department of Civil Engineering, Shandong Jiaotong University, Jinan, Shandong, 250023, China, $2^{\text {nd }}$ International Conference on Electronic \& Mechanical Engineering and Information Technology (EMEIT-2012).

6. Sadrmomtazi A., Fasihi A. Influence of Polypropylene Fibers on the Performance of Nano-Sio2-Incorporated Mortar. Iranian Journal of Science \& Technology, Transaction B: Engineering, Vol. 34, No. B4, PP (385-395) Printed in The Islamic Republic of Iran, 2010 Shiraz University.

7. Tobón J.I, Restrepo O.J, Payá J. Comparative Analysis of Performance of Portland Cement Blended with Nanosilica and Silica Fume. Dyna, May 12th, 2010, 163, PP (37-46).

8. Belkowitz J.S., Armentrout D. An Investigation of Nano Silica in the Cement Hydration Process Concrete Sustainability Conference. National Ready Mixed Concrete Association, 2012, PP (1-15).

9. Sadrmomtazi A., Fasihi A., Balalaei F., Haghi A.K. Investigation of Mechanical and Physical Properties of Mortars Containing Silica Fume and Nano-SiO ${ }_{2}$. The $3^{\text {rd }} \mathrm{In}$ ternational Conference on Concrete and Development, Tehran, Iran, PP (11531161), April 2009.

10. Senff L., Labrincha JOA., Ferreira V.M., Hotza D., Repette W.L. Effect of NanoSilica on Rheology and Fresh Properties of Cement Pastes and Mortars. Construction and Building Materials 23, 8 February 2009, PP (2487-2491).

11. Hakamy A., Shaikh F.U.A., Low I.M. Characteristics of Hemp Fabric Reinforced Nanoclay-Cement Nanocomposites. Cement \& Concrete Composites, 50 (2014), PP (27-35).

12. Patel $K$. The Use of Nanoclay as a Constructional Material. Department Of Civil Engineering, L.D. College of Engineering Ahmedabad- Gujarat, India. Interna- 
tional Journal of Engineering Research and Applications, Vol. 2, Issue 4, JulyAugust 2012, PP (1382-1386).

13. M.S. Morsy, S.H. Sayed Al., Aqel M. Effect of Nano-clay on Mechanical Properties and Microstructure of Ordinary Portland Cement Mortar. International Journal of Civil \& Environmental Engineering IJCEE-IJENS (2010) Vol: 10 No: 01.

14. ES Specification 2421. Determination of Standard Water Cement Ratio for Cement Pastes.

15. ECP 203. Drying Shrinkage of Cement Mortar Containing Portland cement. Egyptian Code for Design and Construction of Concrete Structures, Tests Guide, part 1 PP (62-67), HBRC, Cairo, Egypt, 2003.

16. ASTM C 157-04. Test Method for Length Change of Hardened Hydraulic Cement Mortar and Concrete. ASTM inter, 2004.

17. Zaki. S.I. Assessment of the Durability of Nano Silica / Fly Ash Cement Pastes Exposed to Normal and Aggressive Curing Conditions. Seventh International Conference On Nanotechnology in Construction (NTC 2015), Sharm El-Sheikh, Egypt, March 2015.

18. Zaki S.I., Sobhy I. The Use of Activated Nano Clay to Develop the Compressive Strength and Microstructure of High Performance Concrete. CTU Conference, Concrete in the Low Carbon Era, the University of Dundee, UK, 9-11 July. 2012.

19. Zaki S.I., Ragab K.S., Rashad A.M. The Use of Nano $\mathrm{SiO}_{2}$ to Develop the Water Permeability and Microstructure of High Performance Concrete». International conference on Nano Technology for Green and Sustainable Construction 14-17, Cairo, Egypt, March 2010.

20. Zaki S.I., Ragab K.S. How Nano Technology Can Change Concrete Industry. $1^{\text {st }}$ In- $^{-}$ ternational Conference On Sustainable Built Environment Infrastructures in Developing Countries, ISSN 2170-0095, Oran, Algeria, 12-14 October 2009, vol. 1, PP (407-414).

21. Zaki Saaid I. Assessment of the durability of nanosilica / Fly ash cement pastes exposed to normal and aggressive curing conditions. Nanotehnologii v stroitel'stve = Nanotechnologies in Construction. 2015, Vol. 7, no. 3, pp. 78-99. - DOI: dx.doi. org/10.15828/2075-8545-2015-7-3-78-99.

22. Zaki Saaid I. Application of ultra cellulose fiber for the enhancement of the durability and shrinkage of cement pastes exposed to normal and aggressive curing conditions. Nanotehnologii v stroitel'stve = Nanotechnologies in Construction. 2015, Vol. 7, no. 4, pp. 121-142. DOI: dx.doi.org/10.15828/2075-8545-2015-74-121-142. 
удК 691

Автор: Сааид ЗАКИ, доцент Института материаловедения и контроля качества, Национальный исследовательский центр жилищного строительства, Египет; ул. Тахир, 87, Каир, Египет,

11511, a/s 1770, saaid_zaki@yahoo.com;

Автор: Госсам А. ГОДХОД, Строительный факультет, Университет Каира, ул. Университетская, Гиза, Египет; ул. Тахир, 87, Каир, Египет, 11511, a/я 1770, saaid_zaki@yahoo.com;

Автор: Мустафа А. МАДИ, доцент, инженерный факультет, Университет науки и технологий, Египет; ул. Тахир, 87, Каир, Египет, 11511, a/я 1770, saaid_zaki@yahoo.com.

\section{ВЛИЯНИЕ ГИБРИДНЫХ НАНОМАТЕРИАЛОВ НА УСАДОЧНЫЕ ДЕФОРМАЦИИ ПРИ ГИДРАТАЦИИ И ПРОЧНОСТЬ ЦЕМЕНТНОГО КАМНЯ}

\section{АННОТАЦИЯ К СТАТЬЕ (АВТОРСКОЕ РЕЗЮМЕ, РЕФЕРАТ):}

Целью настоящей работы является экспериментальное выявление закономерностей влияния наноматериалов на показатели цементного теста и цементного камня. Эмпирические исследования включали несколько стадий, на которых были исследованы различные модификаторы: два вида промышленно выпускаемого в Египте нанокремнезема, наноразмерные алюмосиликаты и гибридный наномодификатор на основе нанокремнезема и наноразмерных алюмосиликатов. На каждой стадии объектами исследования являлись цементные пасты и цементный камень. В качестве основной управляющей рецептурной переменной использована концентрация наноразмерных объектов. Исследованы зависимости усадочных деформаций от вида и концентрации наноразмерных объектов. Полученные результаты свидетельствуют, что предел прочности при сжатии наномодифицированного цементного камня достигает максимального значения при концентрациях 1\% и 5\% для нанокремнеземов двух исследованных видов, наноалюмосиликатов и гибридного наномодификатора. При увеличении концентрации всех исследованных наномодификаторов, за исключением наноалюмосиликатов, усадочные деформации при гидратации цементных композиций возрастают.

Ключевые слова: нанокремнезем, наноалюмосиликат, гибридный наномодификатор.

DOI: dx.doi.org/10.15828/2075-8545-2016-8-2-109-134 
МАШИНОЧИТАЕМАЯ ИНФОРМАЦИЯ о СС-ЛИЦЕНЗИИ в МЕТАДАННЫХ СТАТЬИ (НTML-КОД):

$<\mathrm{a}$ rel=»license» href=»http://creativecommons.org/licenses/by/4.0/» ><img alt=» Лицензия Creative Commons» style=»border-width:0» src=»https://i.creativecommons.org/l/by/4.0/88x31.png» $/></ \mathrm{a}><$ br $/>$ Произведение «<span xmlns:dct=»http://purl.org/dc/terms/» href=»http://purl.org/dc/dcmitype/Text»property=»dct:title»

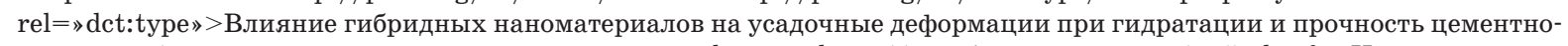
го камня </span> " созданное автором по имени < $<$ xmlns:cc=» http://creativecommons.org/ns\#» href=» Нанотехнологии в строительстве. - 2016. - Том 8, № 2. - C . 109-134. - DOI:dx.doi.org/10.15828/2075-8545-2016-8-2-109-134» property=»cc:attributionName» rel=»cc:attributionURL»> Заки C., Госсам А. Г., Мустафа A.M. </а $>$, публикуется на условиях < $\mathrm{arel=»license»} \mathrm{href=»http://creativecommons.org/licenses/by/4.0/»>лицензии} \mathrm{Creative} \mathrm{Commons} \mathrm{"Attribution»}$ ( «Атрибуция») 4.0 Всемирная $</ \mathrm{a}>$. $<\mathrm{br} />$ Основано на произведении с $<$ a xmlns:dct=»http://purl.org/dc/terms/» href=»http://nanobuild.ru/ru_RU/nanobuild-2-2016/»rel=»det:source»>http://nanobuild.ru/ru_RU/nanobuild-2-2016/</ $\mathrm{a}>$. $<\mathrm{br} />$ Разрешения, выходящие за рамки данной лицензии, могут быть доступны на странице $<\mathrm{a}$ xmlns:cc=»http:// creativecommons.org/ns\#»href=»saaid_zaki@yahoo»rel=»cc:morePermissions»>saaid_zaki@yahoo</a>.

\section{УВАЖАЕМЫЕ КОЛЛЕГИ! \\ ПРИ ИСПОЛЬЗОВАНИИ МАТЕРИАЛА ДАННОЙ СТАТЬИ \\ ПРОСИМ ДЕЛАТЬ БИБЛИОГРАФИЧЕСКУЮ ССЫЛКУ НА НЕЁ:}

Заки С., Госсали А. Г., Мустафа А.М. Влияние гибридных наноматериалов на усадочные деформации при гидратации и прочность цементного камня // Нанотехнологии в строительстве. - 2016. - Том 8, № 2. - C. 109-134. - DOI: dx.doi.org/10.15828/2075-8545-2016-8-2-109-134.

\section{DeAR COlleagues!}

THE REFERENCE TO THIS PAPER HAS THE FOLLOWING CITATION FORMAT:

Zaki Saaid I., Hossam A. Hodhod, Mostafa A. Mahdi. The effect of using hybrid nano materials on drying shrinkage and strength of cement pastes. Nanotehnologii v stroitel'stve $=$ Nanotechnologies in Construction. 2016, Vol. 8, no. 2, pp. 109134. DOI: dx.doi.org/10.15828/2075-8545-2016-8-2-109-134. 